\title{
Pooled endowments: A new funding idea
}

\author{
By Stuart M. Basefsky
}

\section{Publicize your donors on the OPAC}

$\mathbf{T}$ he reasoning behind the specialization of library services into and within the categories of administration, public services, technical services, and so forth has become blurred over time. As a result, it has become difficult to step back and take a focused look at how these interests converge. Roles of individual departments are not necessarily synchronized with the objectives of the library as a whole. Finding effective actions that can play to the needs of each library niche as well as to the general library's goals can be illusive. This article details an example of one successful action. It comes as a result of knowing a desired outcome and raising pertinent questions. It is hoped that other libraries and librarians will find some promise in this initiative.

The concept is that research periodicals and looseleaf services should be completely endowed because they are recurring and predictable costs. The money previously budgeted for these materials could pay for new serial titles, monographs, or electronic information. And OPACs can be used as advertising tools to get donors to pool their endowments to make this an administratively manageable program. This is done by entering the sponsoring individual, family, or corporation into the holdings record and thereby advertising their generosity throughout the world via the Internet.

The idea may seem simple. Getting it accepted, however, is another matter. The library world is complex and the issues surrounding this initiative are full of nuances. This article attempts to explain some of the thinking that went into the proposal.

\section{Issues and thoughts}

The Martin P. Catherwood Library, like other libraries, must cope with overwhelming technological advances, ever-increasing demands for service, and limited, if not diminishing, budgets. Taking a holistic view, I identify several major issues which I see are connected:

1) Inadequate budgets.

2) The often conflicting needs to purchase electronic sources and services while maintaining paper collections.

3) Soliciting unrestricted endowments while avoiding accounting problems which come with multitudes of small endowments.

4) Fincling acceptable reasons to maintain in-house catalogs and catalogers.

5) Generating positive public relations which can be bartered for additional support.

By asking good questions, the interconnectedness of these concerns becomes apparent.

1) Can one identify a major budget problem that presents itself year after year?

In this library the acquisition of research periodicals is identified. This is because periodicals, serials, looseleaf services, etc., tend to be recurring costs which budgets must include each year. These are predictable expenses, ideal for endowments. Additionally, periodicals are the most often used items in this library.

2) Can endowments be identified as the most viable means of solving ongoing budgetary problems in this library?

Yes, without endowments it is virtually impossible to maintain this library as it is and ex- 
pand into electronic media at the same time. Ideally, it would be best to endow our recurring costs-currently purchased research periodicals - and use existing budgets to expand into electronics. Perhaps there has been too great an emphasis placed on reinventing libraries. Reinventing budgets is equally important. Otherwise the call for flexibility to reinvent oneself falls on deaf and poor ears.

3) Are there problems associated with endowments? And can these be solved?

Yes, there are problems with endowments. The major one is multiple accounts. This can be solved, however, by pooling the endowed funds. In other words, no donor gets an endowment in their name, no special account is made in a donor's name. There is only one fund-the pooled endowment-into which all donations go and from which all endowed purchases are made.

4) Is there an appropriate, efficient, and inexpensive way to give recognition to donors? Is this recognition sufficient to convince donors to pool their funds with others? And who in the library is best equipped to maintain this marketing process?

An appropriate way to give recognition to donors is the catalog, which is sufficient to convince donors to give. This is true only because of the existence of OPACs and the Internet. In brief, the catalog should recognize donors who are endowing items appearing in the catalog (see proposal below for details). The ability to have worldwide recognition of one's generosity is better than having a name attached to a fund or, perhaps, even a building.

The answer to the last question is catalogers; they are marketers. The reasoning behind this is: library catalogs are rarely appreciated for their secondary uses. They have always been advertising tools for publishers and authors. They do not simply promote the use of materials in a library. Catalogs provide purchasing information to users and they recommend and often develop the reputations of authors. Printed works in a respected collection acquire some of the image of the library itself. Why then have libraries not expanded these secondary utilities to their advantage? Advertising the generosity of donors, either persons or corporations, can ensure future funding opportunities. Certainly this is one argument in favor of maintaining in-house catalogs and catalogers; they can be directly involved in various forms of marketing.

5) How does one convince donors not to restrict their funds to items of their choice?

By giving donors a preselected list of things to choose from, this problem is largely solved. The donor gets a choice and the library knows what will get chosen (see proposal for details). All donors must be told they can only choose from preselected items; they cannot force a library to purchase unwanted material. Recommendations are welcome, but decisions rest with the librarians.

6) Are there some identifiable reasons why endowments of this nature have not been sought before?

One reason is that development officers take the attitude that spending a lot of time cultivating wealthy donors for large sums of money is better than spending an equal amount of time for smaller sums of money. They are mistaken. Smaller sums of money can be attracted faster and, in fact, are convenient last-minute tax deductions requiring little thought and commitment from the giver. If properly managed, this kind of donation-library pooled endowments - can generate large numbers of donors with good feelings for the institution, thereby increasing the long-term potential of the big donor pool itself. The library can be the "hook" which brings in bigger fish.

\section{Proposal for a "Pooled Endowment for Research Periodicals"}

The Martin P. Catherwood Library at Cornell University should seek to endow its entire periodical collection. Assuming that budgets will force the library to drop important titles to purchase new ones, endowments for the collection will become a necessity. In any event, money for flexible acquisition of labor-management resource material, regardless of format, is in danger because of tight budgets and the general information explosion itself.

Endowments in a library can be a processing nightmare. Separate funds for every part of a collection can create a situation which is labor intensive and mistake prone. Therefore, the following proposal is put forward.

I. Create a pooled endowment. This puts all endowed funds into one large fund. This 
one fund will be used as the source of all endowed periodicals.

II. Make the reward for giving an endowment the placement of the donor's name (or corporate name, family, etc.) in the online catalog. With the Internet providing access to library catalogs, donors can see their names from any location in the world. All students and future students will know the generosity of the donor in association with the periodical endowed. (No named endowments are permitted).

III. Choosing periodicals for endowment. Periodicals should be put into several categories by cost. Journals costing A) less than $\$ 100, \mathrm{~B}$ ) between $\$ 100$ and $\$ 200, C)$ between $\$ 200$ and $\$ 500$, etc., should be selected by collection development and acquisitions. An endowment level for each category should be established artificially high. In other words, for category A the minimum endowment should be $\$ 5,000$. This is done to insure that the investment return on the endowment will always exceed the cost (with inflation concerns) of the journal.

IV. Dealing with title changes. Should the title of the periodical change, inform the donor. Should the title cease, allow the donor to choose another periodical. Possible titles will always be chosen by the library, not by the donor.

If the library follows this plan of action, the online catalog becomes a marketing tool for family and corporate donors. It allows previously hesitant donors to get a "permanent structure" at Cornell in their name. If they like the feeling, they can be approached for more substantial donations. It allows the School of Industrial \& Labor Relations to approach families which are not "wealthy" and which are currently overlooked by development officers.

The above proposal was accepted in September 1993 largely because of an open environment cultivated by the director of the Catherwood Library, Gordon Law. In addition, the practical application of the idea was given life by Phil Dankert, collection development officer, and Chung Kim, head of cataloging.

\section{Comments}

Some librarians take offense at the idea that catalogs can be used as marketing tools. Others regret that libraries have to beg for money. I am sympathetic to these notions. However, taking umbrage is not productive. The problems libraries face today are real and serious.

The pressures placed on libraries by the business world often lead to downsizing, cutting services, outsourcing, and merging operations. These activities are useful and effective when they do not interfere with the basic mission of the library or interfere with the library's ability to give flexibility to the institutions and individuals it serves. When libraries get to the point where they not only see obstacles for themselves but see themselves as obstacles to their clientele, they are in trouble. At some point, libraries have to realize that saving money will not insure their future. They must make money; not in a profit-making sense, but by attracting money to long-term investing in the future. $\mathrm{Li}$ braries must, therefore, take control of budgets to the extent they can. Pooled endowments and OPACs used for advertising are among the many tools which provide this flexibility. 


\title{
A CURE FOR AIDS WILL HAVE TO GET PAST THE FDA.
}

\author{
The World Health Organization.
}

And the Center for Disease Control.

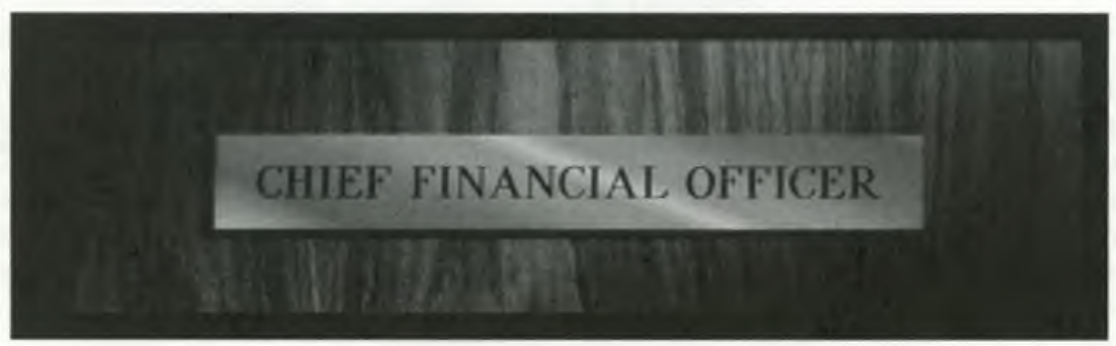

\section{BUT FIRST IT'S GOT TO GET PAST SOMEONE ELSE.}

As much as we'd like to think that profit plays no part in medical breakthroughs, the biotechnology and health care industries are businesses - with justifiable needs to pursue healthy bottom lines. But what if business chose to save money over lives?

You can explore all sides of this and other critical public and social policy issues through PAIS International. PAIS gives you instant access to an index of some 400,000 hard-to-find articles, books, government

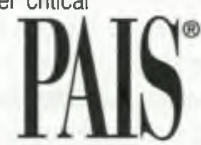

documents, statistical directories and more. It references literature published around the globe. And now it's even available on leased tape.

So if you're looking for information, go through the right channel. Use PAIS.

No one looks at the world like PAls

\section{LEARN ABOUT OUR FORTHCOMING FULL TEXT PRODUCT AT ALA Booth \#2319 in Chicago, June 24-27.}

In Print: PAIS INTERNATIONAL IN PAINT * PAIS SUBJECT HEADINGS Onllne through: DATA-STAR - DIALOG - OCLC - RLG On CD-ROM: PAIS ON CD-ROM - PAIS INTERNATIONAL ON SILVERPLATTEA - PAISIEBSCO CD On MagneIIC Tape: CONTACT PAIS FOR INFORMATION 